\title{
ANALISIS KRIMINOLOGI TERHADAP TINDAK PENYIMPANGAN PERJUDIAN \\ GAME LUDO KING MELALUI APLIKASI GAME PADA SMARTPHONE (STUDI KASUS WILAYAH POLSEK TAMBUSAI UTARA)
}

\author{
Sobri, S.Ip,.Ma \& Randi, S.Sos
}

\begin{abstract}
Technological advancements have brought changes to the whole social order, including games that normally can only be played real-time but are now accessible on smartphones and played online like ludo king games. Increasingly ludo king game has now changed the function of the entertainment arena into a gambling arena. The formation of this gambling event has been influenced by several factors such as economic factors, environmental factors, weak supervision factors, technological development factors. The existence of the learning process is also one of the factors in gambling in ludo king games, so that every one who plays it feels addicted to get money the wrong way. The research method in this case is a qualitative method with the aim of obtaining information by conducting direct observation to the research location and conducting in-depth interviews with key informants and informants.
\end{abstract}

Keywords: Technology, Smartphone, Ludo King Games

\section{PENDAHULUAN}

Masalah kriminalitas dan perilaku menyimpang dalam suatu masyarakat adalah suatu kenyataan sosial dalam kehidupan masyarakat dari dahulu sampai saat ini. Tingkat kriminalitas dan perilaku menyimpang yang ada diperkotaan maupun yang ada di perdesaan semakin meningkat baik dari segi kuantitas maupun kualitasnya. Hal ini disebabkan oleh adanya berbagai perubahan yang sangat cepat diberbagai sektor ilmu pengetahuan dan teknologi yang sangat pesat, serta pertambahan penduduk yang sangat signifikan.

Kemajuan ilmu pengetahuan dan teknologi tentunya turut pula mempengaruhi cara berpikir, bersikap, dan bertindak. Salah satunya dengan perkembangan teknologi seperti smartphone. Penggunaan smartphone saat ini membantu kehidupan manusia mulai dari kehidupan sehari-hari, pekerjaan, dan sebagainya ( Faot, 2013: 2). Dengan adanya smartphone ini dapat menyebabkan 
perubahan sikap, pandangan dan orientasi masyarakat yang mempengaruhi kesadaran hukum dan penilaian terhadap suatu tingkah laku.

Perkembangan game dari masa ke masa semakin menunjukkan kemajuannya. Mungkin dulu kita belum mengenal video game, yang dimainkan hanya permainan di dunia nyata seperti permainan tradisional. Tetapi seiring berkembanganya teknologi smartphone kini permainan bisa dilakukan dirumah sendiri dengan mengunduh beberapa aplikasi game yang disukai (Fitria: 2012).Salah satu contohnya yaitu game ludo king, Ludo king merupakan permainan papan yang sama seperti bermain ular tangga. Ludo king ini bisa dilakukan bersama teman atau pun dengan keluarga. Permainan Ludo amat populer dari zaman dahulu hingga saat ini, hanya struktur permainannya saja yang sedikit bervariasi dan lebih modern. Ludo semakin berkembang di era teknologi digital. Versi digital dari permainan ini dikembangkan dalam bentuk aplikasi. Jenis permainan Ludo berbentuk board game kini banyak dijumpai di smartphone. Selain itu, ada juga developer kreatif yang mengembangkan game ini menjadi lebih bertema dan menarik untuk dimainkan secara digital (Jurnalposmedia: 2017).
Permainan ludo biasanya dimainkan hanya untuk hiburan bersama teman-teman. Namun sekarang menggunakan smartphone, permainan ludo yang dimainkan oleh remaja atau dewasa, permainan ludo ini bukan hanya bertujuan sebagai hiburan saja tetapi sudah disalahgunakan menjadi ajang perjudian.Adapun sistem perjudian ludo ini biasanya dengan cara apabila pemain menendang atau menyingkirkan pion lawan maka pemain yang pionnya tertendang atau kembali keawal, ia harus membayar sesuai dengan kesepakatan. Kemudian 4 pion yang paling cepat finish maka dia pemenangnya dan mendapatkan uang sesuai dengan kesepakatan para pemain dan biasanya untuk perjudian ludo ini pemain pandai dalam menyembunyikan tanda-tanda perjudian, misalnya degan memberi uang taruhan setelah permainan selesai, sehingga kasus perjudian ludo ini sulit untuk di periksa oleh pihak kepolisian.

Kasus perjudian ludo yang pernah diamankan oleh anggtota kepolisian yaitu yang terjadi di Tambusai Utara, Rokan Hulu (Rohul) pada tanggal 21 oktober tahun 2017. Menurut laporan wartawan tribun pekanbaru Donny Saputra, warung motel di Simpang Mansyur Desa Tambusai Utara yang terindikasi sebagai lokasi permainan judi baru jenis ludo king, digerebek oleh anggota 
Polsek Tambusai Utara, Rokan Hulu (Rohul). Dimana, pada penggerebekan dilakukan Sabtu malam (21/10/2017) sekitar pukul 22.45 WIB, anggota Polsek Tambusai Utara menciduk 4 laki-laki yang diduga sedang asik bermain judi jenis ludo king. Ipda Suheri mengaku, pada penggerebekan tersebut polisi sita barang bukti, terdiri 1 smartphone xiomi redmi 3 pro warna hitam silver, serta uang tunai Rp 255 ribu. Empat laki-laki dan barang bukti tersebut, langsung digelandang ke Mapolsek Tambusai Utara untuk proses penyidikan lebih lanjut. (TribunRohul : 2017)

Dampak dari perjudian ludo melalui aplikasi HP ini sangatlah merugikan sekali bagi diri sendiri dalam hidup bermasyarakat karena Perbuatan judi merupakan perilaku yang melanggar terhadap kaidah-kaidah, nilai-nilai, dan norma-norma yang ada dalam masyarakat, sehingga akan mendapatkan Sanksi masyarakat misalnya dikucilkan oleh masyarakat, dipergunjingkan, tidak dihargai dan lain sebagainya. Individu yang melakukan tindakan berjudi terdorong motif untuk memperoleh keuntungan yang sebesarbesarnya (utility maximitation) bagi kesejahteraannya. Walaupun judi dilarang dan diancam dengan hukuman, masih saja banyak yang melakukannya. Hal itu antara lain karena manusia mempunyai kebutuhan dasar yang harus dipenuhi, sedangkan di sisi lain tidak setiap orang dapat memenuhi hal itu karena berbagai sebab misalnya karena tidak mempunyai pekerjaan atau mempunyai penghasilan lain untuk memenuhi kebutuhan mereka. Atau dapat juga mempunyai pekerjaan tetapi tidak cukup untuk memenuhi kebutuhan pokok mereka. Pilihan mereka untuk menambah kekurangan kebutuhan tersebut adalah antara lain pilihannya melakukan judi dan perjudian, judi menjadi alternatif yang terpaksa dilakukan meskipun mereka tahu risikonya, untuk mencukupi kebutuhannya dan keluarganya.

\section{KERANGKA KONSEPTUAL}

\section{Perilaku Menyimpang}

Menurut Hurlock (1998) menjelaskan bahwa tingkah laku menyimpang adalah tingkah laku yang dianggap tercela, tingkah laku yang melanggar aturan-aturan serta nilai-nilai sosial. tingkah laku penyimpang perjudian adalah tingkah laku yang dianggap tercela, melanggar norma-norma, nilai-nilai sosial yang dihasilakan dari suatu stimulus negatif sehingga menyebabkan respon terhadap tingkah laku individu untuk melakukan tindak perjudian. Dimana, stimulus negatif yang terbentuk bukan 
karena kemampuan individu itu sendiri melainkan adanya pengaruh dari luar diri individu yang menyebabkan individu tersebut meresponnya dengan cara yang salah, yang akhirnya menimbulkan suatu penyimpangan.

\section{Game ludo King}

Ludo king merupakan permainan papan yang sama seperti bermain ular tangga. Ludo king ini bisa dilakukan bersama teman atau pun dengan keluarga. Sejarah permainan Ludo bisa dilacak dari abad ke-6 di India. Ludo sendiri berasal dari permainan Pachisi, dan juga sangat mirip dengan Parchis, permainan papan dari Spanyol yang sering di mainkan oleh pendeta kristen.Permainan Ludo amat populer dari zaman dahulu hingga saat ini, hanya struktur permainannya saja yang sedikit bervariasi dan lebih modern. Ludo semakin berkembang di era teknologi digital. Versi digital dari permainan ini dikembangkan dalam bentuk aplikasi. Jenis permainan Ludo berbentuk board game kini banyak dijumpai di smartphone. Selain itu, ada juga developer kreatif yang mengembangkan game ini menjadi lebih bertema dan menarik untuk dimainkan secara digital (Jurnalposmedia: 2017).
Berikut cara bermain ludo menurut Harita (2014), yaitu:

a. Langkah pertama adalah pilih 4 pion yang sama warnanya, lalu letakkan pada 4 lingkaran di area yang sama warnanya dengan pion (dalam permainan ini biasanya disebut dengan rumah awal).

b. Kemudian leemparlah dadu secara bergantian dengan para pemain lain. Giliran pertama yang memperoleh angka dadu terbesar, diikuti yang lain sesuai besar angka dadu yang diperoleh.

c. Untuk melangkahkan pion, pemain harus mendapat angka dadu 6 (aturan ini bisa tidak dipakai, tergantung dengan kesepakatan para pemain).

d. Setelah itu, lempar dadu dan gerakkan pion ke kotak jalur luar sesuai arah panah, sesuai dengan jumlah angka dadu yang diperoleh. Apabila pemain mendapat angka dadu 6 maka berhak melempar dadu lagi. Namun bila sampai ke-3 kalinya masih mendapat angka 6 maka pemain tidak boleh bergerak lagi.

e. Ketika pion telah mengelilingi sirkuit dan sampai di jalur berwarna di areanya, pemain harus mendapat 
angka dadu yang tepat nilainya untuk mencapai rumah akhir.

f. Pemenangnya adalah pemain yang paling cepat meletakkan ke-4 pion di rumah akhir.

Adapun Kelebihan permainan ludo ini menurut Harita (2014), yaitu:

a. Kognitif, kemampuan mengetahui dan mengingat.

b. Motorik, kemampuan mengkoordinasikan anggota tubuh seperti tangan dan kaki.

c. Logika, kemampuan berpikir secara tepat dan teratur.

d. Emosional/Sosial, kemampuan merasakan dan menjalin hubungan interpersonal.

e. Kreatif/Imajinatif, kemampuan menghasilkan ide sesuai dengan konteks.

f. Visual, kemampuan mata menangkap bentuk dan warna obyek.

Dan Kekurangan dari permainan ludo ini menurut Harita (2014) yaitu :
a. Tidak dapat dimainkan secara individu atau sendiri.
b. Cukup memakan waktu yang lama

\section{Perjudian}

Menurut Dali Mutiara, dalam tafsiran KUHP yang dikutip oleh Dr, Kartini Kartono dalam bukunya Patologi Sosial menyatakan sebagai berikut: Permainan judi ini diartikan dengan arti yang luas, juga termasuk segala pengetahuan tentang kalah menangnya suatu pacuan kuda atau lain-lain pertandingan, atau segala pertaruhan dalam perlombaan-perlombaan itu, misalnya totalisator dan lain sebagainya (Kartono, 2001: 52). Sedangkan menurut R.M. Suharto judi adalah tiap-tiap permainan yang pengharapan untuk menang bergantung padda hal yang kebetulan, nasib, peruntungan, yang tidak dapat direncanakan serta diperhitungkan (Suharto, 1993:52 dalam Ricky, 2016).

Berbeda dengan Suharto, Bonger (R.Soesilo,1981:179 dalam Ricky, 2016) mengemukakan bahwa "perjudian adalah perbuatan bermain dengan mempertaruhkan uang”. Dalam hal ini Bonger memberikan penafsiran terhadap judi lebih singkat dan pada intinya adalah permainan yang mempertaruhkan uang. Menurut undangundang Hukum Pidana pasal 303 ayat 3, perjudian itu dinyatakan sebagai berikut: Main judi berarti tiap-tiap permainan yang kemungkinan akan menang pada umunya tergantung pada untung-untungan saja, juga kalau kemungkinan bertambah besar, karena 
pemain lebih pandai atau lebih cakap. Main judi mengandung juga segala pertaruhan tentang keputusan perlombaan atau permainan lain yang tidak diadakan oleh mereka yang turut berlomba atau main itu, demikian juga segala pertaruhan lainnya.

\section{KAJIAN TEORI}

\section{Teori Differential Assosiation}

Teori Sosialisasi atau teori belajar ini menyebutkan bahwa penyimpangan perilkau adalah hasil dari belajar. Salah seorang ahli teori belajar ang banyak dikutip tulisannya adalah Edwin $\mathrm{H}$. Sutherland (dalam Suyanto dan Naryoko, 2011: 112). Ia menamakan teorinya dengan Asosiasi Diferensial. Menurut Sutherland, penyimpangan adalah konsekuensi dari kemahirandan penguasaan atas suatu sikap atau tindakan yang dipelajari dari norma-norma yang menyimpang, terutama dari subkultur atau diantara teman-teman sebaya yang menyimpang (Suyanto dan Naryoko, 2011: 112).

Teori Asosiasi diferensial dapat diterapkan untuk menganalisis organisasi sosial atau subkultur (baik yang menyimpang atau tidak), penyimpangan perilaku di tingkat individual, perbedaan norma-norma yang menyimpang ataupun tidak, terutama pada kelompok atau asosiasi yang berbeda (Suyanto dan Naryoko, 2011: 112). Ditingkat kelompok, perilaku penyimpangan adalah konsekuensi dari terjadinya konflik normative. Artinya, perbedaan aturan sosial di berbagai kelompok sosial, seperti: sekolah, lingkungan, tetangga, kelompok teman sebagaya atua keluarga.

Adapun beberapa faktor yang mempengaruhi pilihan pelaku dalam melakukan perilaku penyimpangan perjudian ludo king adalah:

a. Keuntungan Dari Dilakukannya perilaku perjudian

Dalam teori pilihan rasional, kegunaan untuk melakukan tindak kejahatan berdasarkan keseimbangan individu dan biaya untuk melakukan kejahatan dengan alternative dalam artian pelaku yang telah dilakukan akan mendapatkan hadiah sebagai imbalannya dan ini menjadi faktor yang dominan, kuat dan sulit untuk dilakukan dengan cepat walaupun diberikan hukuman yang berat bagi yang melanggarnya.

b. Sarana Dalam Aktifitas Ilegal Individu didorong oleh keinginan atau tujuan dalam melakukan kejahatan mereka bertindak dengan spesifik, 
mengingat kondisi dan hambatan atas dasar informasi yang mereka milliki tentang kondisi dimana mereka bertindak karena tidak mungkin bagi individu untuk mencapai semua dari berbagai hal yang mereka inginkan, mereka juga harus membuat pilihan dalam kaitannya dengan tujuan mereka dan sarana untuk mencapain tujuantujuan itu.

c. Kemungkinan Resiko Tertangkap dan Tuntut

Dalam melakukan kejahatan teori pilihan rasional memandang seseorang pelaku kejahatan mempertimbangkan banyak manfaat yang akan didapat dari kejahatan dan pada kerugian yang akan ditentukan maka pelaku akan mengindar penangkapan.

d. Pemberian Hukuman

Bagi pelaku ancaman bukanlah menjadi pertimbangan mereka dalam melakukan kejahatan, namun dengan beberapa pertimbangan dalam kasus kejahatan, ancaman hukuman tidak lagi menjadi penghalang bagi pelaku untuk melakukan kejahatan, para pelaku berfikir bahwa mereka akan mendapatkan keuntungan dari kejahatan dan mereka yakin mereka tidak akan mendapatkan hukuman yang lama jika tertangkap.

Dengan adanya perjudian memberi jalan pintas bagi individu yang lemah untuk dapat memenuhi suatu tujuan dengan berjuta harapan tanpa harus bekerja keras, mereka waras secara jernih berfikir dan menurut mereka dengan berjudi hal itu tidak merugikan pihak lain atau tidak adanya korban secara riil. Sebagai contoh: mereka tidak mencuri hak orang lain dan mereka tidak merampok, tetapi mereka hanya bermain judi demi keuntungan individu.

\section{METODE PENELITIAN}

Peneliti ini menggunakan metode pendekatan kualitatif metode studi kasus. Menurut Akbar dan Usman (2009: 78) penelitian kualitatif dilakuan dalam situasi yang wajar (natural setting) dan data yang dikumpulkan umumnya bersifat kualitatif , pendekatan kualitatif adalah suatu proses penelitian dan pemahaman yang berdasarkan pada metodologi yang menyelidiki suatau fenomena sosial dan masalah manusia. Pada pendekatan ini, peneliti membuat suatu gambaran kompleks, meneliti kata-kata, laporan terperinci dari pandangan responden, dan melakukan studi pada situasi yang alami. Penelitian studi kasus ini diarahkan untuk menghimpun data, 
mengambil makna, dan memperoleh pemahaman dari kasus tersebut. Suatu kasus tidak dapat mewakili populasi dan tidak dimaksudkan untuk memperoleh kesimpulan dari populasi. Kesimpulan studi kasus hanya berlaku bagi kasus yang teliti, karena tiap kasus bersifat unik dan memiliki karakteristik yang berbeda antara yang satu dengan yang lain.

Untuk memperoleh informasi dilakukan penelitian dengan cara observasi secara langsung ke lokasi penelitian serta melakukan wawancara mendalam terhadap key informan dan informan. Melalui pendekatan tersebut dimungkinkan peneliti dapat menguraikan kompleksitas masalah di mana kawasan hukum polsek Tambusai Utara dan dilingkungan masyarakat Penyasawan terdapat kegiatan perjudian ludo kingilegal, di dalam prakteknya disinyalir memprakarsai aktivitas-aktivitas penyimpangan.

\section{DESKRIPSI LOKASI PENELITIAN}

Kabupaten Rokan Hulu memiliki berbagai macam suku dan ragam budaya, sebagian besar merupakan keturunan suku Melayu Rokan dan Mandailing. Selain itu terdapat pula suku Jawa, Minang Kabau, Sunda, Batak dan masih terdapat adanya masyarakat terasing yaitu suku Bonai dan
Suku Sakai, dua suku pertama dan suku terakhir merupakan suku asli Rokan Hulu. Kecamatan yang paling padat penduduknya adalah kecamatan Ujung Batu 494 jiwa/km2 diikuti oleh Pagaran Tapah Darussalam 128 jiwa/km2.

Masyarakat Rokan Hulu masing sangat kuat memegang teguh budaya dan tradisi kesehariannya. Hukum dan Adat masih berpengaruh dalam kehidupan bermasyarakat, terlihat dengan upacara perkawinan, penyambutan tamu negeri dan acara budaya lainnya. Rokan Hulu terletak di Barat Laut Pulau Sumatera pada 1000 1010 52' bujur timur dan 00-15'-10 30' lintang utara. Kabupaten yang diberi julukan Negeri Seribu Suluk ini mempunyai luas wilayah 7.449,85 $\mathrm{km}^{2}$ dan berbatasan langsung dengan :

a. Sebelah utara berbatasan dengan Provinsi Sumatera Utara dan KabupatenRokan Hilir.

b. Sebelah barat berbatasan dengan Provinsi Sumatera Utara dan Sumatera Barat.

c. Sebelah Timur berbatasan dengan Kabupaten Kampar, Bengkalis dan Siak.

d. Sebelah Selatan berbatasan dengan Provinsi Sumatera Barat. 
Kabupaten Rokan Hulu berada pada ketinggian 70-86 Meter dari permukaan laut. Disebelah Barat Kabupaten mempunyai kontur tanah yang bergelombang yang merupakan bagian pegunungan bukit barisan sedangkan sebagaian besar lainnya merupakan daerah rendah yang subur, dimana $85 \%$ terdiri dari dataran dan $15 \%$ rawa-rawa dan perairan terdapat tiga buah sungai besar yaitu :
a. Sungai Rokan Kiri.
b. Sungai Rokan Kanan.
c. Sungai Sosah.

Kabupaten Rokan Hulu dibagi kedalam 16 daerah Kecamatan yaitu Bangun Purba, Bonai Darussalam, Kabun, Kepenuhan, Kepenuhan Hulu, Kunto Darussalam, Rambah, Rambah Hilir, Rambah Samo, Rokan IV Koto, Tambusai,Tambusai Utara, Tandun, Ujungbatu, Pagaran Tapah Darussalam dan Pendalian IV Koto. Kabupaten Rokan Hulu tergolong daerah beriklim tropis dengan temperatur udara berkisar antara 220-310, terdapat dua musim yaitu musim hujan dan musim kemarau. Musim kemarau pada umumnya terjadi antara bulan maret sampai dengan agustus sedangkan musim hujan terjadi bulan September sampai dengan Januari.

\section{ANALISA}

Hasil penelitian ini berfokus pada apa saja faktor penyebab maraknya fenomena perjudian ludo king diwilayah Hukum Polsek Tambusai Utara Rokan Hulu. Menurut informasi yang penulis dapat oleh kapolsek Tambusai Utara, bahwasannya perjudian ludo king ini merupakan jenis perjudian baru yang menggunakan sarana smartphone, dimana penagkapan perjudian ini pertama kali dilakukan pada tanggal 22 Oktober 2017 di simpang tiga Mansur RT 002 Desa Tambusai Utara Kec. Tambusai Utara Kab. Rokan Hulu. Perjudian ludo king termasuk perjudian terbaru yang di selidiki oleh kepolisian. Di wilayah Polsek Tambusai Utara menurut informasi banyak terjadi perjudian ludo king dikalangan remaja sampai dewasa.

Permainan ludo king mulai trending dikalangan masyarakat sejak awal tahun 2017, dimana permainan ini awalnya hanya sebagai hiburan saat sedang berkumpul dengan teman-teman, tetapi berawal sebagai hiburan semata kini ludo king digunakan sebagai perantara mendapatkan pundi-pundi uang dari kemenangan atau disebut judi ludo king. Kebanyakan pemain judi ludo king ini dikarena faktor lingkungan bermain dengan teman sebaya, banyaknya akses dalam 
melakukan perjudian dan dorongan dari pertemanan membuat individu yang lemah terdorong untuk melakukan perbuatan yang sama yaitu judi ludo king. Berdasarkan datadata hasil penelitian yang didapati peneliti dilapangan brdasarkan data primer dan data sekunder, dapat digambarkan bahwa meluasnya fenomena perilaku menyimpang dalam bentuk perjudian ludo king berbasiskan android diwilayah Hukum Polsek Tambusai Utara Rokan Hulu dipengaruhi oleh berbagai faktor, yaitu seperti faktortekanan ekonomi, pengaruh lingkungan, kecanduan/kebiasaan, lemahnya pengawasan serta lemahnya penghayatan tentang agama serta pengaruh dari perkembangan teknologi.

Banyaknya aktifitas perjudian di kawasan tersebut karena lemahnya faktor tekanan ekonomi masyarakat yang membuat mereka memilih bermain judi ludo king dengan harapan-harapan untuk menang dan mendapatkan banyak uang. Harapan mendapatkan unag dari berjudi ini didasari karena sikap malas untuk bekerja, sulitnya pekerjaan, atau karena ketidakpuasan atas apa yang sudah dimilikinya. Dan kenyataannya bahwa judi tidak akan pernah memenuhi ekonomi tetapi akan membuat perekonomian semakin sulit.
Para pelaku judi ludo king berharap dengan cara tersebut mereka bisa mengadu nasib keberuntungan mendapatkan uang kalau mereka menang.pejudi menggantungkan harapannya dengan cara mencari jalan pintas untuk mendapatkan sumber pendapatan lain dengan cara bermain judi. Bermain judi ludo king menurut mereka lebih aman dibandingkan bermain judi lainnya, karena ludo king bisa dimainkan dimana saja dan tidak ketahuan orang lain karena alat permainan smartphone yang tidak mencolok untuk dikenali sebagai alat bermain judi. Hal ini berhubungan dengan teori Anomie yang dikemukakan oleh Merton (dalam Clinard \& Meier, 1989: 81) bahwa suatu keadaan dari situasi dimana kondisi sosial masyarakat lebih menekankan pentingnya tujuan-tujuan status, tetapi struktur sosial tidak dapat menyediakan kesempatan yang sama bagi semua orang untuk meraih tujuan status, sehingga untuk mencapai tujuan statusnya mereka terpaksa melakukannya dengan melalui cara-cara yang tidak sah, diantaranya penyimpangan perjudian ini.

Selain faktor tekanan ekonomi yang menjadi alasan seseorang melakukan perjudian, yaitu pengaruh lingkungan. Lingkungan merupakan tempat seseorang bersosialisasi dan menemukan jati diri. 
Seseorang yang bergaul dengan orang lain di lingkungannya yang pekerjaannya memang bermain judi, maka suatu saat nanti akan sangat gampang terjerumus dan ikut menjadi penjudi, karena setiap hari yang mereka saksikan adalah perjudian, sehingga lama kelamaan menjadi kebiasaan.Lingkungan tempat tinggal seseorang sangat berpengaruh terhadap karakter yang bersangkutan. Kalau ingin sesuatu yang baik, maka perilaku/ pergaulan orang itu pun akan baik, tetapi sebaliknya jika bergaul dengan seorang pemain judi maka kemungkinan akan terpengaruh sehingga ikut bermain judi juga. Mungkin hal demikianlah sehingga perjudian itu diistilahkan sebagai salah satu penyakit masyarakat yang hingga saat ini sangat sulit untuk diberantas. Hal ini lah yang terjadi di wilayah Hukum Polsek Tambusai Utara, kebanyakan dari pelaku bermain judi ludo king karena terpengaruh oleh ajakan teman yang akhirnya membuat kebiasaan terus bermain judi ludo king.

Pengaruh lingkungan ini berhubungan dengan terori sosialisasi atau teori belajar yang dikemukakan Edwin $\mathrm{H}$. Sutherland (dalam Suyanto \& Naryoko, 2011: 112). Bahwa penyimpangan adalah konsekuensi dari kemahiran penguasaan atas suatu sikap atau tindakan yang dipelajari dari norma-norma yang menyimpang, terutama dari subkultur atau diantara temanteman sebaya yang menyimpang. Dan Boger (1982: 87) berpendapat bahwa, harus diakui bahwa peniruan dalam masyarakat mempang mempunyai pengaruh yang lebih besar sekali. Keisengan dan coba-coba hingga akhirnya menjadi kecanduan atau kebiasaan juga mempengaruhi seseorang untuk ikut bermain judi.Adanya kesempatan atau waktu kosong kerap kali digunakan untuk bermain judi.Misalnya seorang remaja yang tidak memiliki kegiatan lain setelah sekolah maka dia mengisi waktu kosong bersama teman-temannya untuk bermain ludo king dari handphone mereka, karena merasa bosan mereka pun mencoba mengunakan taruhan uang, yang membuat lama-kelamaan menjadi ketagihan atau kecanduan hingga merasa bermain judi ludo king ini sebagai kegemaran atau kebiasaan yang harus dilakukan.

Hal ini disebabkan karena masyarakat yang ingin melakukan tindak pidana perjudian berpikir hanya dengan sedikit modal saja, maka akan mendapatkan hasil yang banyak, atau sesuai dengan keinginan yang dikehendaki. Judi ini merupakan salah satu bentuk hiburan, sehingga seringkali menjadi pelarian dari kegiatan atau rutinitas, kebosanan, dan kesibukan sehari-hari. Judi adalah safety 
valve-katup penyelamat, yaitu suatu alat untuk memenuhi aspirasi, sehingga para pecandu judi ini akan melampiaskan kemarahan, frustasi, dan kekecewaan yang mereka alami. Judi membuat orang pada awalnya hanya mencoba saja, tetapi lama kelamaan akan membuat orang selalu berharap, karena judi ini menjanjikan suatu kemenangan atau perbaikan kehidupan sosial para pecandunya.

Lemahnya pengawasan baik dari orang tua/keluarga, lingkungan ataupun pengawasan hukum, membuat pemain menjadi merasa aman dalam melakukan aktifitas tersebut, karena tidak adanya penertiban di warung-warung tempat biasa mereka nongkrong, ataupun tidak adanya pengawasan dari orang tua dan masyarakat. Pengawasan semakin sulit dilakukan karena media android yang digunakan untuk bermain judi ludo king merupakan media umum yang dikenali untuk bermain judi, sehingga sulit dikenali orang sedang berjudi atau tidak. Oleh karena judi berbasis android member pengaruh meluasnya perilaku menyimpang di dalam masyarakat, hal ini tergambarkan di dalam penelitian saya, anak-anak bahkan ibu-ibu bermain judi ludo king yang mana sebelumnya bermain judi di dominasi oleh orang dewasa laki-laki. Hal ini karena judi berbasis android sudah ada maka dapat dilakukan oleh semua golongan.

Adapun faktor kecanduan atau kebiasaan, dan faktor lemahnya pengawasan hal ini berhubungan dengan teori control yang dikemukan oleh Hirschi (1969) dalam Suyanto \& Naryoko, 2011: 116), bahwa penyimpangan merupakan hasil dari kekososongan control atau pengendalian sosial. Teori ini dibangun atas dasar pandangan bahwa setiap manusia cenderung untuk tidak patuh pada hukum atau memiliki dorongan untuk melakukan pelanggaran hukum. Penyimpangan dan bahkan kriminalitas atau perilaku criminal, merupakan bukti kegagalan kelompokkelompok sosial konvensional untuk mengikat individu agar tetap conform, seperti keluarga, sekolah, atau institusi pendidikan dan kelompok-kelompok dominan lainnya.

Pada dasarnya semua Agama dan adat istiadat membimbing kita pada kebaikan dan kebenaran, lemahnya pengaruh nilai agama seseorang membuat orang yang lemah perekonomiannya menghalalkan segala cara untuk memenuhi kebutuhan hidupnya, serta didukung oleh rendahnya pendidikan membuat mereka berpikir tidak rasional dikarenakan rendahnya pendidikan membuat mereka tidak menyadari 
perbuatnanya itu salah dalam agama. Faktor lemahnya penghayatan agama ini berhubungan dengan teori agama, yaitu perilaku menyimpang disebabkan karena lemahnya kadar iman dan taqwa, belum dihayatinya ajaran agama, kemiskinan yang menghimpit, dan besarnya godaan dari luar dan godaan hawa nafsu.

Salain faktor tekanan ekonomi, pengaru lingkungan, faktor kecanduan atau kebiasaan, faktor lemahnya pegawasan, dan faktor lemahnya pengamatan agama yang memfaktori seseorang malakukan tindakan penyimpangan perjudian ludo king, pengaruh dari perkembangan teknologi juga salah-satu faktor yang sangat berpengaruh. Perkembangan teknologi seperti handphone membuat para pamain ludo traditional beralih dengan menggunakan handphone yang mereka anggap lebih praktis, dan lebih nyaman karena akan sulit untuk diselidiki.

Dari sekian banyak faktor yang mempengaruhi faktor meluasnya perilaku menyimpang perjudian ludo king oleh masyarakat di kecamatan tambusasi utara rokan hulu, berdasarkan hasil penelitian ini menjadi faktor kemajuan ilmu pengetahuan dan teknologi khususnya game berbasis adroit adalah menjadi faktor dominan yang mempengaruhi meluasnya perilaku perjudian di masyarakat.
Salah satu perkembangan teknologi komunikasi di dunia yang berpengaruh dengan tingkah laku dan menyebabkan timbulnya perilaku menyimpang yaitu Handphone.Salah satu bentuk penyimpangan yang terjadi karena pengaruh dari penggunaan handphone yaitu Perjudian ludo king yang merupakan salah satu dampak dari perkembangan teknologi, karena pada era sebelum permainan ludo merupakan jenis permainan papan yang menggunakan media kertas dan hanya sebagai permainan untuk hiburan anak-anak atau remaja saja. tetapi sekarang pemainan ludo melalui media handphone.

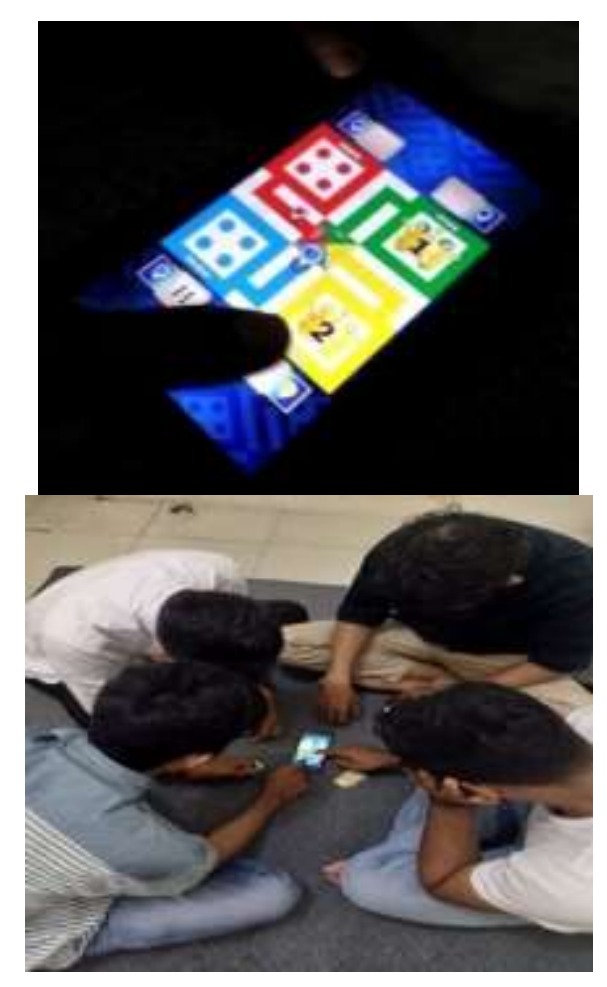


Gambar : Permainan ludo king melalui aplikasi android

Perkembangan perjudian ludo king bukan dari media nya saja yang berubah dari media kertas menjadi media handphone, tetapi pemakai/konsumtifnya juga mulai berkembang, dulu permainan judi ludo menggunakan kertas biasa dimainkan oleh laki-laki desawa di tempat yang tersembunyi, misalnya di belakang rumah atau di perkebunan.Dengan adanya perkembangan teknologi komunikasi berupa handphones Sekarang pemakai/konsumtif judi sudah mulai berkembang, yaitu seperti anak-anak bahkan perempuan sudah ikut terlibat dalam perilaku menyimpang judi ludo king. Tidak hanya pelaku tetapi tempat atau lokasi yang dijadikan untuk berjudi pun sekarang dapat dilakukan dimana saja, seperti di rumah, dikedai-kedai dll, hal ini karena perjudian ludo king yang berbasis android tidak mudah dipantau sebagai perbuatan penyimpangan.

Faktor perkembangan teknologi dan perubahan tingkah laku penyimpangan perjudian ludo king melalaui aplikasi handphone berhubungan dengan teori penyimpangan sosial jenjang makro dari R.K Merton dari bentuk adaptasi terhadap situasi media pembentuk perilaku menyimpang. "Perilaku yang dilakukan oleh seseorang terjadi karena adanya media yang menjadi pencetus sekaligus yang mendorong terbentuknya kepribadian yang menyimpang”. Handphone yang berisi aplikasi ludo king menjadi pencetus dan memfasilitasi perilaku menyimpang perjudian jenis ludo king, yang dulunya menggunakan media kertas kini beralih ke media elektronik.

\section{KESIMPULAN}

Berdasarkan hasil analisis dan pemahaman yang telah penulis uraikan maka penulis mengambil keputusan, yang menjadi faktor penyebab seseorang di wilayah hukum polsek Tambusai Utara melakukan perjudian jenis ludo king secara umum disebabkan oleh beberapa faktor yaitu: Faktor tekanan Ekonomi,Pengaruh Lingkungan, Faktor Kecanduan atau kebiasaan, faktor lemahnya pengawasan, faktor lemahnya penghayatan terhadap Agama serta pengaruh dari perkembangan teknologi. Semakin maraknya perjudian ludo king melalui handphone di wilayah polsek Tambusai Utara antara lain juga dikarenakan: tersedianya waktu luang yang tidak dapat digunakan untuk kegiatankegiatan lain. Pola hidup yang konsumtif yang di barengi dengan berkurangnya gairah 
kerja dan sekolah. Tersedianya sarana dan alat perjudian yang mudah di perolehdan digunakan. Sikap dan pandangan hidup individu dan masyarakat terhadap perjudian itu sendiri.

\section{SARAN}

Menarik dari kesimpulan pemaparan pada bab sebelumnya dan juga kesimpulan yang telah disebutkan diatas, penulis dapat memberikan beberapa saran sebgai berikut:

a. Melihat semakin maraknya perjudian, khususnya perjudian ludo king melalui handphone, Maka disarankan kepada para pihak polsek Wilayah Tambusai Utara untuk lebih meningkatkan mutu profesionalisme dan daya

b. antisipasinya secara aktif dalam mencegah dan memberantas perjudian di Tambusai Utara.

a. Menjadikan jadwal rutin bagi pihak kepolisian dalam melaksanakan operasi rutin terhadap tempat-tempat yang di jadikan sarana bermain judi.

b. Bagi masyarakat disarankan supaya berperan aktif dengan memberikan laporan kepada pihak kepolisian, apabila mengetahui dan melihat kegiatan perjudian, khusunya perjudian ludo king. Agar pihak Kepolisian Tambusai Uatara lebih mengoptimalkan koordinasi dan kerjasama antara pihak-pihak terkait untuk melaksanakan penyuluhan hukum secara rutin dan berkelanjutan tentang larangan bermain judi, khusunya judi ludo king.

c. Agar Pemerintah Republik Indonesia lebih bijak dalam membentuk peraturan-peraturan yang memberikan dampak hukum yang lebih positif dan mampu menyadarkan serta meminimalkan segala bentuk kejahatan di Negara Republik Indonesia.

\section{DAFTAR PUSTAKA}

Anwar, Ricky. 2016. Analisis Kriminologi

Terhadap Perjudian Toto Gelap

(TOGEL) (Studi Kasus Wilayah

Hukum Polsek Lima Puluh Kota

Pekanbaru). Pekanbaru:

Universitas Islam Riau.

Akbar, Setiady dan Usman, Husaini. 2009.

Metodologi Penelitian Sosial.

Jakarta: Bumi Aksara 
Departemen Pendidikan dan

kebudayaan.1989 Kamus Besar

Bahasa Indonesia. Jakarta : Balai

Pustaka.

Fitria. 2012.

Https://Fitria.wordpress.com/2012/ perkembangan-teknologi-gamepada-mobile/. (Diakses, 19 Oktober 2017).

Foat, kris Demiarto. 2013. Tinjauan

Kriminologis Terhadap Tindak

Pidana Perjudian Kupon Putih di

Timika Papua (Studi Kasus 2008-

2012), Makasar: Universitas

Hasanudin Makasar.

Harita, mella. 2014.

mellaharita.blogspot.co.id. Diakses

: 1 Desember 2017.

Huwirtz, Stephen. 1986. Kriminologi.

Jakarta: Bina Aksara.

Jurnal media pos, 2017,

http://jurnalposmedia.com/ludo-

king-permainan-papan-era-digital/.

(Diakses, 20oktober 2017)

Kartono, Kartini. 2005. Patologi Sosial. Jilid

I. PT. Grafindo Persada : Jakarta.

TribunRohul.

2017.Pekanbaru.tribunnews.com/2 017/10/23/tengah-asik-main-gameludo-king-di-warung-empat-priadigelandang.com. (Diakses, 24

Oktober 2017).

Suharto, R.M. 1993. Hukum Pidana

Materiil. Jakarta: Sinar Grafika.

Suyanto, Bagong dan Narwoko, Dwi. 2004. Sosiologi Teks Pengantar dan Terapan. Jakarta: Prenada. 